\title{
RENEGOSIASI SEBAGAI UPAYA PENYELESAIAN WANPRESTASI DALAM KONTRAK BISNIS SELAMA MASA PANDEMI COVID-
}

\author{
Arya Bangbang Frisyudha, I Nyoman Putu Budiartha, Ni Komang Arini Styawati \\ Fakultas Hukum, Universitas Warmadewa, Denpasar - Bali, Indonesia \\ aryayudha52@gmail.com, budiarthaputu59@gmail.com, arinistyawati@gmail.com
}

\begin{abstract}
Abstrak
Kebijakan pemerintah akibat penyebaran Covid-19 menimbulkan dampak perekonomian yang melemah karena pembatasan aktivitas masyarakat yang juga berdampak pada kegiatan bisnis termasuk pelaksanaan kontrak bisnis. Pelaksanaan hak dan kewajiban kontrak bisnis terhambat bahkan timbul kemungkinan tidak terlaksana yang mengakibatkan wanprestasi. Salah satu kontrak yang menimbulkan wanprestasi selama pandemi adalah sektor perbankan yang mengacu pada kontrak kredit. Metode penelitian yang digunakan adalah penelitian hukum normative dengan pendekatan perundang-undangan dan pendekatan konseptual. Teknik pengumpulan bahan hukum yang diterapkan pada penelitian ini yaitu studi Pustaka yang berupa literatur, jurnal maupun hasil penelitian terdahulu serta studi dokurnen. berupa kumpulan dokumen resmi dengan penafsiran dan pengkajian melalui peraruran perundang-undangan berdasarkan sumber hukum primer dan sekunder. Penelitian ini bertujuan untuk mengetahui Akibat hukum renegosiasi terhadap pelaksanaan kontrak bisnis dan peran pernerintah dalam upaya penyelesaian wanprestasi kontrak bisnis selama masa pandemi. Hasil penelitian menunjukkan bahwa Akibat hukum renegosiasi terhadap pelaksanaan kontrak bisnis selama masa Pandemi Covid-19 menimbulkan itikad baik dari para pihak dalam kontrak dimana kedua pihak bertindak dengan rnempertimbangkan kepentingan pihak yang lain begitu pula dengan masa pandemi saat ini dimana kreditur harus memperhatikan kepentingan debitur dan peran Pernerintah dalam upaya penyelesaian wanprestasi kontrak bisnis selama masa pandemi adalah dengan melakukan kebijakan yang bersifat countercyclical.
\end{abstract}

Kata Kunci: Kontrak Bisnis, Upaya Penyelesaian, Renegosiasi, Wanprestasi.

\begin{abstract}
Government policies due to the spread of Covid-19 have caused a weakening economic impact due to restrictions on community activities as well as business activities including the implementation of business contracts. The realizing of the rights and obligations of the business contract is hampered, and even there is the possibility that it will not be carried out which caused non-performance of contract. One of the contracts that caused it during the pandemic is the banking sector which refers to credit contracts. The research method used is normative research with statutory and approach. The technique of collecting materials applied in this research is literature research in the form of literature, journals and the results of previous research and documentary studies. in the form of a collection of the documents with interpretation and review through statutory regulations based on primary and secondary legal sources. This research aims to determine the legal consequences of renegotiation on the implementation of business contracts and the role of the government in settling business contract defaults during the pandemic period. The results shows that the legal consequences of renegotiation on the implementation of business contracts during the Covid-19 pandemic have generated goodwill from the parties in the contract where both parties act with consideration of the interests of the other party as well as during the current pandemic where creditors must pay attention to the interests of the debtor and the role The government in its efforts to settle business contract defaults during the pandemic is to implement a countercyclical policy.
\end{abstract}

Keywords: Business Contract, Settlement Effort, Renegotiation, Non-Performance of Contract.

\section{PENDAHULUAN}

Keputusan Presiden Republik Indonesia Nomor 12 Tahun 2020 menetapkan penyebaran sebuah virus Corona Virus Disease 2019 menjadi Bencana Nasional Non Alam. Covid-19 menimbulkan pemberlakuan kebijakan baru dari pemerintah terkait pembatasan kegiatan masyarakat seperti lockdown, social distancing, physical distancing, maupun work from home. Perekonomian melemah 
akibat pembatasan aktivitas berdampak pada ruang gerak bisnis yang mengakibatkan pelaksanaan hak dan kewajiban dalam kesepakatan kontrak bisnis terhambat atau bahkan tidak terlaksana sama sekali karena bisnis tidak berjalan lancar. Dalam hukum perdata, apabila suaru kesepakatan telah memenuhi syarat sahnya perjanjian sesuai Pasal 1320 KUH Perdata maka berdasarkan Pasal 1338 KUH Perdata kesepakatan tersebut berlaku sebagai Undang-Undang bagi para pihak yang membuatnya. Namun, dalam pelaksanaannya kontrak tidak selalu terlaksana dengan baik. Terdapat keadaan dirnana kewajiban atau prestasi tidak terpenuhi yang disebut dengan ingkar janji atau wanprestasi. Dampak hukum dari wanprestasi dapat menyebabkan suatu kontrak dapat dibatalkan atau batal demi hukum. (Elly Erawati, 2010:5)

Penyebaran Covid-19 merupakan situasi dimana kontrak sangat berat untuk dilaksanakan. Namun, terdapat kemungkinan unruk tetap dilaksanakan berdasarkan dengan asas itikad baik yang dapat memungkinkan terlaksananya prestasi yang adil bagi para pihak. Dengan berdasar pada Pasal 1338 KUH Perdata yang menyebutkan tentang pelaksanaan kontrak dengan itikad baik menjadi norma yang dapat dijadikan dasar bagi para pihak untuk menjalankan langkah penyelesaian wanprestasi terbaik bagi kelangsungan kontrak.

Covid-19 membawa dampak hukum untuk para pihak agar melakukan peninjauan kembali isi kontrak yang tidak sesuai lagi dengan kondisi saat ini. Dengan negosiasi para pihak dapat melahirkan bentuk-bentuk kesepakatan yang saling mempertimbangkan kepentingan rnasing-rnasing (Agus, 2008: 1). Untuk tetap dapat mempertemukan kepentingan masing-masing pihak dalam kondisi seperti penyebaran Covid-19 saat ini, terdapat proses renegosiasi atau peninjauan kembali. Dengan renegosiasi atau peninjauan kembali isi menjadi upaya hukum dalam memberikan perlindungan dan kepastian hukum bagi para pihak dalam pelaksanaan kontrak dan rnenyempurnakan hal yang tidak termuat sebel um terjadinya penyebaran Covid-19.

Dari berbagai kegiatan bisnis yang beroperasi dalam sistem perekonomian akan menghasilkan berbagai macam kontrak bisnis contohnya dari sektor finansial yaitu perbankan yang mengacu pada kontrak kredit. Kebijakan terkait munculnya virus Covid-19 membawa dampak pada kewajiban yang harus dipenuhi oleh debitur untuk membayar utang terhadap kreditur dengan jangka waktu yang telah disepakati sesuai kontrak kredit. Wanprestasi tersebut timbul akibat ketidakmampuan debitur untuk memenuhi prestasi kepada kreditur.

Dalam transaksi bisnis seringkali terjadi wanprestasi yang berdampak luas terhadap perencanaan bisnis sehingga dapat merugikan aspek finansial maupun non finasial seperti nama baik (goodwill) dan kepercayaan bisnis (business trust). Akibat Hukum dari wanprestasi adalah pihak yang tidak dapat melaksanakan perjanjian harus bertanggung jawab mengganti kerugian obyek yang telah disepakati diawal (Aminah, 2020). Namun renegosiasi dapat dilaksanakan dengan tujuan membatalkan atau mengubah isi kontrak yang telah disepakati sebelumnya dan tentunya diharapkan adanya itikad baik. Suatu kontrak harus tetap dilaksanakan sesuai dengan isinya sesuai dengan ketentuan Pasal 1338 KUH Perdata yang menyatakan setiap perjanjian yang dibuat secara sah berlaku sebagai undang-undang bagi yang membuatnya (Arini et al., 2020)

Maka berdasarkan uraian diatas, penelitian ini bertujuan untuk mengetahui Akibat hukum renegosiasi terhadap pelaksanaan kontrak bisnis dan peran pernerintah dalam upaya penyelesaian wanprestasi kontrak bisnis selama masa pandemi.

\section{METODE PENELITIAN}

Tipe penelitian yang diterapkan pada penelitian ini adalah metode penelitian hukum normatif. Metode ini mengkaji hukum dari perspektif internal yuridis baik melalui norma hukum, konsep hukum, asas hukum dan doktrin hukum (Pasek Diantha, 2017:93). Pendekatan masalah yang digunakan untuk menafsirkan dan mengkaji data dalam penelitian ini adalah pendekatan perundang-undangan dan pendekatan konseptual. Penelitian ini menggunakan tiga sumber hukum yaitu bahan hukum primer, sekunder dan tersier (Amiruddin,dkk, 2008:163). Teknik pengumpulan bahan hukum yang diterapkan pada penelitian ini yaitu studi Pustaka yang berupa literatur,jurnal maupun hasil penelitian terdahulu.serta studi dokurnen. berupa kumpulan dokumen resmi dengan penafsiran dan pengkajian melalui peraruran perundang-undangan. 


\section{HASIL DAN PEMBAHASAN}

\section{Akibat Hukum Renegosiasi Terhadap Pelaksanaan Kontrak Bisnis Selama Masa Pandemi Covid-19}

Kebijakan pemerintah selama panderni mengakibatkan kendala pada aktivitas masyarakat contohnya pada kegiatan perekonomian termasuk dalam dunia bisnis. Beberapa aktivitas bisnis di Indonesia seperti terhambatnya proses produksi, terhentinya industri pariwisata, tempat hiburan dan perhotelan hingga ditutupnya maskapai penerbangan guna terlaksananya kebijakan pembatasan sosial dan penutupan wilayah. Hal ini menimbulkan hambatan dalam pelaksanaan kontrak bisnis antara suatu pihak mitra. Pada sektor perbankan khususnya kontrak bisnis dalam kredit, kebijakan physical distancing dan work from home juga berdampak pada kewajiban yang harus dipenuhi oleh debitur untuk membayar utangnya sesuai dengan jangka waktu yang telah disepakati dalam kontrak bersama kreditur.

Kontrak kredit menimbulkan hubungan hukum antara pihak kreditur yang berhak menurut sesuaru dan pihak debitur yang berkewajiban untuk memenuhi tuntutan. Apabila tuntutan tersebut tidak dipenuhi, pihak yang memiliki piutang atau kreditur dapat menuntut pihak debitur di depan hakim atau dengan kata lain, apabila pihak berhutang atau debitur tidak melakukan apa yang telah diperjanjikan, maka kreditur dapat menuntut debitur dengan dasar wanprestasi atau ingkar janji (Fitri, 2020)

Hubungan bisnis dalam sektor perbankan terjadi antara pengusaha selaku debiturdan bank selaku kreditur. Untuk menjalankan usahanya debitur memerlukan bantuan modal dari Lembaga konvensional yaitu bank. Bank selaku kreditur menjadi fasilitator pengadaan modal bagi debitur dalam bentuk pinjaman. Hubungan bisnis yang mengikat dalam kontrak merupakan utang dan transaksi pinjaman. Selama masa pandemi, Sebagian kasus yang terjadi adalah debitur yang merupakan pengusaha mikro, kecil, dan menengah yang tengah mengembangkan usahanya telah melakukan pinjaman kredit di bankjauh sebelum terjadinya Covid-19.

Seperti halnya yang dialami salah satu pengusaha mikro, kecil, dan menengah di daerah Padangsambian, Denpasar Barat yaitu Toko kain Putri Rahmani. Toko ini merupakan UMKM yang memulai usahanya di Tahun 2019. Untuk mengembangkan usahanya maka dilakukannya pinjaman kepada salah satu Bank Pemerintah di daerah Denpasar Selatan. Pinjaman Toko kain Putri Rahmani menimbulkan hubungan hukum yang terikat dengan kontrak kredit. Toko tersebut selaku debitur memiliki pinjaman yang bemilai lebih dari Rp. 10.000.000, - kepada Bank Pemerintah selaku kreditur. Pinjaman dilakukan sebelum terjadinya pandemi Covid-19 di Indonesia. Tepat di bulan Juli Tahun 2020, Toko kain Putri Rahmani ini menjadi salah satu usaha UMKM yang terkena dampak pandemi Covid-19. Dengan masuknya status Covid-19 sebagai bencana Nasional di bulan Maret 2020, mengakibatkan perekonomian masyarakat Indonesia menurun, hal ini berdampak pada daya beli konsumen terhadap barang maupun jasa.

Toko kain Putri Rahmani menjadi salah satu nasabah di Bank Pemerintah di Bali yang terkena dampak dari kebijakan pemerintah dalam pembatasan jam kerja sehingga mempengaruhi jumlah penjualan serta pemasukan yang menurun drastis. Begitu pula dengan kondisi modal Toko kain Putri Rahmani selaku debitur dan nasabah yang mengalami penurunan karena banyak barang yang tidak terjual sehingga mengakibatkan perputaran modal pada debitur terganggu dan menyebabkan terjadinya kendala dalam membayar angsuran sesuai kontrak kredit.

Hubungan bisnis dalam bentuk kontrak kredit antara Toko kain Putri Rahmani sebagai debitur dan Bank Pemerintah sebagai kreditur menimbulkan kewajiban debitur yairu Toko kain Putri Rahmani untuk membayar utang atas pinjamannya terhadap kreditur berdasarkan jaruh tempo yang telah disepakati dalam kontrak. Namun, dengan menurunnya daya beli konsumen mengakibatkan Toko kain Putri Rahmani mengalami kendala dalam memenuhi prestasi atas pinjaman terhadap kreditur karena menurunnya pendapatan toko akibat keadaan perekonomian masyarakat yang tidak stabil. Toko kain Putri Rahmani menjadi salah satu contoh pengusaha atau debitur yang dikatakan wanprestasi terhadap kontrak karena dampak dari Covid-19.

Wanprestasi yang terjadi karena debitur tidak melakukan wanprestasi sebagaimana yang telah disepakati karena kesengajaan dan/atau lalai tidak melaksanakan wanprestasinya menurut KUH Perdata debitur wajib membayar biaya ganti rugi dan bunga sebagaimana yang diatur dalam Pasal 1239 sampai dengan Pasal 1242 KUH Perdata. Namun, dengan situasi yang tak terduga seperti penyebaran Virus Corona saat ini menjadi faktor penyebab yang tidak dapat diduga dan di luar 
kesalahan debitur sehingga tidak dapat dipertanggungjawabkan kepada debitur (Agustina, dkk, 2012:5).

Dalam penyelesaian wanprestasi oleh debitur di masa pandemic, kreditur dapat memberikan kesempatan kepada debitur untuk melakukan suatu penyelesaian dengan melakukan renegosiasi (peninjauan kembali) kontrak demi mencapai negosiasi untuk memperpanjang masa kelonggaran bagi debitur terhadap pembayaran utang pokok dengan memberikan waktu lebih lama untuk jatuh tempo dari angsuran hutang pokok atau dengan memberikan kesempatan kepada debitur untuk membayar utang secara cicilan. Menegosiasikan kembali isi kontrak menjadi upaya yang lebih baik dari pembatasan kontrak.

Renegosiasi kontrak antara kreditur dengan debitur yang terikat dalam kontrak kredit menjadi upaya yang tidak bisa terlepas selama masa pandemi ini. Untuk menghindari keadaan dimana debitur tidak memenuhi prestasinya atau wanprestasi dengan dalil covid-19 maka perlu memperhatikan negosiasi ulang isi kontrak kredit dalam bentuk restrukturisasi kredit yang berdasarkan pada UndangUndang Nomor 2 Tahun 2020 tentang Kebijakan Keuangan Negara dan Stabilitas Sistem Keuangan untuk Penanganan Pandemi Covid-19 maupun Peraturan OJK Nomor 1 1/POJK.03/2020 mengenai kebijakan bagi bank yang mendukung stimulus pertumbuhan ekonomi untuk debitur yang terkena dampak penyebaran Covid-19 termasuk debitur UMKM. Dengan melakukan renegosiasi atau negosiasi kembali isi kontrak, maka debitur dalam mengajukan permohonan restrukturisasi utang. Restrukturisasi utang dapat dilakukan sebagai upaya menanggulangi kredit macet akibat menurunnya penghasilan debitur dampak Covid-19.

\section{Peran Pemerintah Dalam Upaya Penyelesaian Wanprestasi Kontrak Bisnis Selama Masa Pandemi Covid-19}

Kontrak yang bersengketa dapat menimbulkan konsekuensi yuridis yaitu adanya upaya penyelesaian. Secara teoritis upaya penyelesaian sengketa dapat ditempuh melaJui jaJur litigasi dengan prosedur formaJ dan perantara pengadilan (Joses, Jimmy 2011:9). Selama masa pandemi, sengketa yang terjadi adalah wanprestasi oleh debitur yang mempakan pengusaha mikro, kecil, dan menengah telah melakukan pinjaman kredit di Bank jauh sebelum terjadinya Covid-19. Berdasarkan itikad baik dirasa kurang patut apabila kontrak tetap dituntut pelaksanaannya dalam situasi dan kondisi Covid-19 yang didukung dengan pernyataan pemerintah bahwa Covid-19 mempakan bencana nasional non-alam, Hal ini menjadi hak bagi para pihak untuk menuntut penyesuaian syarat-syarat kontrak dalam menyesuai kan isi kontrak dengan keadaan yang baru. Apabila terdapat perbedaan pendapat antara para pihak maka upaya penyelesaian sengketa agar dapat mengedepankan musyawarah sehingga penyelesaian sengketa dapat diselesaikan dengan waktu dan biaya yang

murah juga dapat menghasilkan win-win solution.

Melalui Peraturan Otoritas Jasa Keuangan Republik Indonesia nomor 11/POJ K.03/2020 kebijakan countercyclical diterapkan dengan memberikan perlakuan khusus kepada kredit Bank dengan jumlah tertentu atau dengan memberikan restrukturisasi atau relaksasi bagi pembayaran kredit oleh debitur yang terkena dampak penyebaran Covid- pada sektor ekonomi.

Kebijakan lanjut dalam hal kontrak bisnis antara debitur dan kreditur yang terikat dengan utang-piutang, pemerintah Indonesia telah membentuk kebijakan di bidang perekonomian melalui Peraturan Menteri Koordinator Bidang Perekonornian Republik Indonesia Nomor 8 Tahun 2020 tentang Perubahan atas Peraturan Menteri Koordinator Bidang Perekonornian Nomor 6 Tahun 2020 tentang Perlakuan Khusus Bagi Penerima Kredit Usaha Rakyat Terdampak Panderni Coronavirus Disease 2019, pada Pasal 6 Ayat (I) menyebutkan bahwa penerima KUR terdampak pandemi Covid19 dapat rnemperoleh ketentuan khusus KUR berupa:

a. Pemberian penundaan angsuran pokok KUR selama paling lama 6 (enam) bulan sesuai penilaian penyalur KUR yakni mulai berlaku I April 2020 dan paling lama sampai dengan 31 Desember 2020; dan/atau

b. Relaksasi ketentuan berupa pemberian restrukturisasi KUR berupa

1. Perpanjangan jangka waktu KUR

2. Penambahan limit plafon KUR

3. Penundaan pemenuhan pembayaran kredit 
Melalui informasi dari salah satu debitur usaha rnikro, kecil, dan menengah dalam penelitian ini yakni Toko kain Putri Rahmani, Pernerintah telah melakukan upaya penyelesaian wanprestasi bagi debitur yang terkena dampak Covid-19 dengan rnelakukan manajemen risiko Covid-19. Manajemen resiko ini dilakukan dengan mengefektifkan pengambilan angsuran yang dijalankan setiap hari dengan nominal uang berapapun yang debitur berikan dalam mernenuhi cicilan pembayaran Bank tetap menerima.

\section{SIMPULAN DAN SARAN}

\section{Simpulan}

Akibat hukum renegosiasi terhadap pelaksanaan kontrak bisnis selama masa Pandemi Covid-19 dalam hal hubungan hukum pengusaha mikro, kecil dan rnenengah dengan Lembaga finansial yaitu Bank menimbulkan itikad baik dari para pihak dalam kontrak dimana kedua pihak bertindak dengan rnempertimbangkan kepentingan pihak yang lain begitu pula dengan masa pandemi saat ini dimana kreditur harus memperhatikan kepentingan debitur. Dalam hal ini kreditur diharap dapat memberikan kesernpatan kepada debitur untuk melakukan penyelesaian hambatan atas ketidakmampuannya rnembayar angsuran dengan diperbolehkan mengajukan renegosiasi atau peninjauan kembali kontrak demi rnencapai kesepakatan bersama Peran Pernerintah dalam upaya penyelesaian wanprestasi kontrak bisnis selama masa pandemi adalah dengan melakukan kebijakan yang bersifat countercyclical melalui Peraturan Otoritas Jasa Keuangan Republik Indonesia Nomor 1 1/POJK.03/2020 tentang StimulusPerekonomian nasional yang bertujuan mendorong kemampuan perbankan khususnya fungsi intermediasi, menjaga kestabilan sistem keuangan serta mendukung pertumbuhan ekonomi. Bentuk kebijakan countercyclical adalah dengan rnemberikan perlakuan khusus kepada kredit Bank dengan jumlah tertentu atau dengan menrestrukturisasi kredit kepada debitur yang terkena dampak penyebaran Covid-19.

\section{Saran}

Saran yang dapat diberikan terhadap permasalahan pada penelitian ini yaitu :

a. Bagi pemerintah agar dapat mengenmbangkan peraturan perundang-undangan serta peraturan pemerintah mengenai renegosiasi kontrak bisnis untuk dapat memberikan keadilan, kemanfaatan dan kepastian hukum bagi para pihak dalam kontrak apabila terjadi peristiwa yang tidak terduga seperti Covid-19.

b. Bagi pihak dalam kontrak, agar debitur dan kreditur yang terikat pada suatu kontrak bisnis di masa pandemi Covid-19 dan dapat melakukan regonesiasi kontrak bisnis melalui perpanjangan jangka waktu kredit, penurunan atau penghapusan suku bunga maupun syarat lain demi tercapainya winwin solution dalam kontrak

c. Bagi peneliti-peneliti selanjutnya agar dapat mengembangkan isi dari penelitian ini dengan melakukan penyesuaian regulasi atau peraturan perundang-undangan dan kebijakan terkait pelaksanaan kontrak bisnis selama pandemi Covid-19

\section{DAFTAR PUSTAKA}

Agustina, Rosa. (2012). Hukum Perikatan (Law of Obligations). Pustaka Larasan, Jakarta.

Aminah. (2020). Pengaruh Pandemi Covid 19 Pada Pelaksanaan Perjanjian. Diponegoro Private Law Review, 7(1), 650-656.

Amiruddin \& H. Zainal Asikin. 2008. Pengantar Metode Penelitian Hukum, Edisi I. PT. Raja Grafindo Persada, Jakarta

Arini, A. D., Corona, P., Alasan, S., \& Majeur, F. (2020). Pandemi Corona Sebagai Alasan Force Majeur Dalam Suatu Kontrak Bisnis. 9(1), 41-56.

Diantha, I Made Pasek. (2017). Metode Penelitian Hukum Normatif dalam Justifikasi Teori Hukum, Prenada Media Group. Jakarta.

Erawati, Elly \& Herlien Budiono. (2010). Penjelasan Hukum Tentang Kebatalan Perjanjian, Nasional Legal Reform Program Grarnedia, Jakarta. 
Fitri, W. (2020). Implikasi Yuridis Penetapan Status Bencana Nasional Pandemi Corona Virus Disease 2019 (COVID-19) Terhadap Perbuatan Hukum Keperdataan. Supremasi Hukum: Jurnal Kajian Ilmu Hukum, 9(1), 76-93.

Hernoko, Agus Yudha. (2009). Hukum Perjanjian: Asas Proporsionalitas dalam Kontrak Komersial, Kencana Prenada Group, Jakarta.

Joses, Jimmy. (2011). Cara Menyelesaikan Sengketa di Luar Pengadilan. Visimedia, Jakarta. 